\title{
Mercury release flux and its influencing factors at the air-water interface in paddy field in Chongqing, China
}

\author{
ZHU JinShan ${ }^{1}$, WANG Ding Yong ${ }^{1,2^{*}} \&$ MA Ming ${ }^{1}$ \\ ${ }^{1}$ Key Laboratory of Eco-environments in Three Gorges Reservoir Region of the Ministry of Education, College of Resources and Environment, \\ Southwest University, Chongqing 400715, China; \\ ${ }^{2}$ Chongqing Key Laboratory of Agricultural Resources and Environment, Chongqing 400716, China
}

Received February 2, 2012; accepted May 5, 2012; published online October 18, 2012

\begin{abstract}
The exchange of mercury $(\mathrm{Hg})$ across the air-water interface is an important part of $\mathrm{Hg}$ biogeochemical cycle. Mercury fluxes across the air-water interface in paddy fields were measured by a Dynamic Flux Chamber (DFC) coupled with a Lumex ${ }^{\circledR}$ multifunctional mercury analyzer RA-915 ${ }^{+}$at two sites (Chengjiang (CJ) and Caoshang (CS)) in Beibei, Chongqing, China in 2008. The results showed that mercury emission followed a power-law relationship with solar radiation and air temperature, and it increased exponentially with water temperature at both sites. Mercury emission was mainly influenced by the solubility of gaseous elemental $\mathrm{Hg}$, photo-thermal effect, electron activity (Eh) and air $\mathrm{Hg}$ concentrations. Solar radiation made the greatest direct contribution to mercury emission during the daytime (0.80), with an $83.60 \%$ contribution, whereas at nighttime the water temperature (0.72) contributed to $71.65 \%$ of emissions. The temperature gradient between water and air might also influenced mercury emission across the air/water interface at nighttime. These findings suggest that paddy fields could act as a significant source of atmospheric mercury, and it can contribute significantly to the atmospheric mercury in a local region.
\end{abstract}

mercury fluxes, air/water surface, paddy field, environmental factors

Citation: Zhu J S, Wang D Y, Ma M. Mercury release flux and its influencing factors at the air-water interface in paddy field in Chongqing, China. Chin Sci Bull, 2013, 58: 266-274, doi: 10.1007/s11434-012-5412-8

Rice is the world's single most important food crop and a primary food source for more than half of the world's population. Its growing area accounts for $11 \%$ of the global cultivated land, ranking second only to wheat [1,2]. Rice paddy fields are the second largest wetland type in the world [2]. Mercury (Hg) is of utmost concern as a pollutant in paddy soils because of its strong tendency to bioaccumulate via the food chain, posing ever-higher health and ecological risks [3].

Previous studies have shown the importance of the terrestrial environment as a significant mercury source in the global mercury cycle. It has been estimated that approximately $80 \%$ of the mercury deposited on the terrestrial surface is re-emitted back to the atmosphere through surface emission [4]. Mercury emissions have been extensively

*Corresponding author (email: dywang@swu.edu.cn) investigated in forests [5,6], wetlands [7,8], grasslands [9] and deserts [10]. However, $\mathrm{Hg}$ emissions from paddy fields have not been well studied. Kim et al. [11] measured the mercury fluxes at the soil/air interface in a rice paddy with relatively dry, non-irrigated soil in Korea and found that rice paddy could behave as both source and sink of mercury. However, mercury fluxes across the water/air surface were ignored during the flooding period.

An accurate assessment of mercury fluxes across the water/air surface is the key to better understand of the underlying mechanisms [11]. Gustin et al. [12] recently showed that data should be collected over $24 \mathrm{~h}$ as a function of diel climatic factors to estimate $\mathrm{Hg}$ flux more accurately. To the best of our knowledge, there is little information available about major factors controlling air $\mathrm{Hg}$ exchange with water in paddy field.

The objectives of this study were (1) to investigate the 
release flux of mercury across the air/water surface in paddy field at two sites in Beibei, Chongqing, China, and (2) to examine the relationships between mercury fluxes and various environmental factors using various statistical techniques, including correlation analysis, regression, principal component analysis and path analysis.

\section{Materials and methods}

\subsection{Site description}

Two sites, Chengjiang (CJ) and Caoshang (CS), were chosen for this study. Both sites are located in Beibei district of Chongqing, southwestern China, with a north latitude of $29^{\circ} 55^{\prime} 16.4^{\prime \prime}$ and an east longitude of $106^{\circ} 22^{\prime} 11.7^{\prime \prime}$ for CJ, and a north latitude of $29^{\circ} 45^{\prime} 26.0^{\prime \prime}$ and an east longitude of $106^{\circ} 26^{\prime} 12.0^{\prime \prime}$ for CS. They are about $22 \mathrm{~km}$ apart. Paddy fields at both sites were flooded with the water level maintained at 5-10 cm during the fallow and as high as 10-15 $\mathrm{cm}$ during the growing season. The soil is Typic Purpli-Udic Cambosols at CJ and Allitic-Udic Ferrosols at CS (Figure 1).

\subsection{Materials and methods}

(1) Technique for mercury flux measurement. Mercury flux at the interface (air/water) was measured by using a Dynamic Flux Chamber (DFC) coupled with a Lumex ${ }^{\circledR}$ multifunctional mercury analyzer RA- $915^{+}$operated by CVAAS plus Zeeman Correction, $1-\mathrm{Hz}$ data stream (Lumex $^{\circledR}$, Russia). A schematic diagram for the system was given by Wang et al. [13]. The flux chamber measures 20 $\mathrm{cm} \times 20 \mathrm{~cm} \times 60 \mathrm{~cm} \mathrm{[14]} \mathrm{and} \mathrm{its} \mathrm{volume} \mathrm{is} 0.024 \mathrm{~m}^{3}$. Quartz glass was chosen for the chamber because of its transparency to light and potential to achieve low chamber blanks. The chamber was linked through the outlet with the Multifunctional mercury analyzer by semi-transparent Teflon $^{\mathrm{TM}}$ tube (internal diameter of $0.635 \mathrm{~cm}$ ). A known volume of ambient air was drawn into the chamber through the inlet ports to measure $\mathrm{Hg}$ flux.

(2) Field measurement of mercury flux. Mercury flux at the air/water interface was measured using a flux chamber. A styrofoam block was used to provide buoyancy for

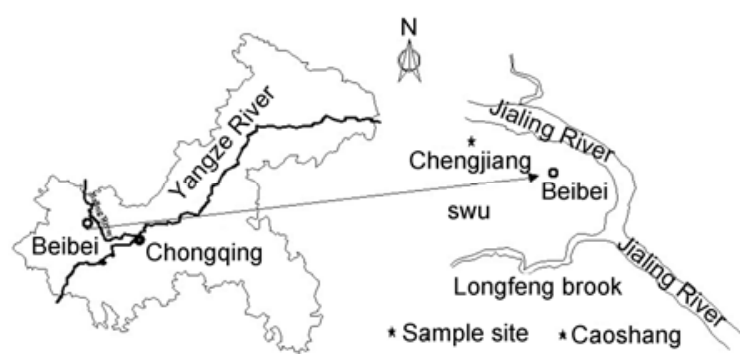

Figure 1 Schematic diagram of two study sites, Beibei, Chongqing, China. the chamber $[15,16]$. The floating chamber system was immersed $1 \mathrm{~cm}$ below the water surface to ensure a tight seal with the water. Ambient air was pulled through the flux chamber to the Lumex ${ }^{\circledR}$ Multifunctional mercury analyzer (sampling flow rate $=20 \mathrm{~L} / \mathrm{min}$, each air sampling time $=5$ min). Both inlet $\left(C_{\mathrm{i}}\right)$ and outlet $\left(C_{\mathrm{o}}\right)$ mercury concentrations were continuously and alternately monitored. A $5 \mathrm{~min}$ average of $C_{\mathrm{o}}$ and a $5 \mathrm{~min}$-average of $C_{\mathrm{i}}$ were used to obtain an average $\mathrm{Hg}$ flux $(F)$ from eq. (1) $[17,18]$ :

$$
F=\frac{\left(C_{\mathrm{o}}-C_{\mathrm{i}}\right) Q}{A},
$$

where $F$ is the flux $\left(\mathrm{ng} /\left(\mathrm{m}^{2} \mathrm{~h}\right)\right), C_{\mathrm{i}}$ and $C_{\mathrm{o}}$ are total gas mercury (TGM) concentrations of the DFC inlet and outlet in $\mathrm{ng} / \mathrm{m}^{3}$, respectively. $Q$ is flushing flow rate through the chamber in $\mathrm{m}^{3} / \mathrm{h}\left(1.2 \mathrm{~m}^{3} / \mathrm{h}\right.$ for all measurements in the present study). $A$ is the area of the open bottom surface of the chamber $\left(\mathrm{m}^{2}\right)$. The positive and negative $F$ calculated from eq. (1) represent net $\mathrm{Hg}$ emission flux and net $\mathrm{Hg}$ dry deposition flux, respectively.

The Hg exchange fluxes were measured monthly over 24 to $48 \mathrm{~h}$ at each measurement in March, June, July, September and November at Caoshang site, and April, May, June, October and November at Chengjiang site in 2008. Hg exchange fluxes were not measured in August as there was no water in the paddy field in that month.

The chamber blanks were obtained by measuring the mercury flux over a clean Teflon ${ }^{\mathrm{TM}}$ sheet in the field at both the beginning and end of each measurement date at each site. The chamber blanks ranged from 0.63 to $0.84 \mathrm{ng} /\left(\mathrm{m}^{2} \mathrm{~h}\right)$, with an average of $0.73 \pm 0.06 \mathrm{ng} /\left(\mathrm{m}^{2} \mathrm{~h}\right)$.

(3) Measurement of mercury in soil and water. Surface soil and water samples were collected from each site. Soil samples were sealed in clean plastic bags. Water samples were collected and stored in acid-cleaned high-density polyethylene centrifuge tubes. After being transported to the lab, water samples were preserved in a refrigerator (at $4^{\circ} \mathrm{C}$ ) before $\mathrm{Hg}$ analysis. Soils were air-dried, milled and sieved to pass through a 100 mesh screen. Soil samples were then digested with $\mathrm{H}_{2} \mathrm{SO}_{4}-\mathrm{HNO}_{3}-\mathrm{KMnO}_{4}$ in a water bath $\left(90^{\circ} \mathrm{C}\right)$. After cooling, the samples were allowed to stand for $24 \mathrm{~h}$, and $0.2 \mathrm{~mL} \mathrm{NH} \mathrm{N}_{2} \mathrm{OH} \cdot \mathrm{HCl}$ solution $(20 \mathrm{~g}$ of reagent grade $\mathrm{NH}_{2} \mathrm{OH} \cdot \mathrm{HCl}$ dissolved in $100 \mathrm{~mL}$ Milli-Q water) was then added to destroy excessive potassium permanganate $\left(\mathrm{KMnO}_{4}\right)$ before adding stannous chloride $\left(\mathrm{SnCl}_{2}\right)$ to convert $\mathrm{Hg}(\mathrm{II})$ to volatile $\mathrm{Hg}(0)$. Mercury concentrations in the solutions were determined by cold vapor atomic fluorescence spectrometry (CVAFS) [13]. Two standard soil samples, GBW 07405 (GSS-5) and GBW 07406 (GSS-6), were included for quality control of the $\mathrm{Hg}$ analysis. The precision of our method obtained from replicate analyses was less than $5 \%$. For triplicate digestions, the relative standard deviations were also less than $5 \%$.

(4) Measurement of environmental parameters. Solar radiation was monitored using a TES ${ }^{\circledR}$-II Digital Luminom- 
eter (Taiwan, China) with a time resolution of 10 min which matched to the 10 min sampling times ( 5 min for inlet and another $5 \mathrm{~min}$ for outlet) of $\mathrm{Hg}$ exchange fluxes obtained. Water temperature was measured with a FlashCheck ${ }^{\circledR}$ Pocket Probe Digital Thermometer11000 (Delta TRAK, USA). Water Eh (ORP) was measured with Pen-type potentiometer DW-1 (Jiangsu, China). Other environmental parameters (including air temperature, relative humidity and atmospheric pressure) were also measured with Kestrel $^{\circledR}$ 4000 pocket weather ${ }^{\mathrm{TM}}$ Tracker $^{\mathrm{TM}}$ (Nielsen-Kellerman, USA).

(5) Statistical methods. Statistical procedures including correlation analysis, regression, principal component analysis and path analysis were used to examine the relationships between mercury fluxes and various environmental factors. Partitioning the correlation coefficient into direct and indirect effects can be done through path analysis technique. The principal components analysis is a multivariate statistical technique for exploration and simplifying complex data sets. Appropriate statistical analysis was done using Excel 2003 and SPSS 13.0 packages.

\section{Results and discussion}

\subsection{Mercury concentrations in air, soil, water and mercury fluxes}

Average mercury concentration in paddy field soil was $0.062 \pm 0.007 \mathrm{mg} / \mathrm{kg}(n=5)$ at $\mathrm{CJ}$, and $0.079 \pm 0.010 \mathrm{mg} / \mathrm{kg}$ $(n=5)$ at CS, respectively. Both were higher than the background value $(0.0493 \mathrm{mg} / \mathrm{kg})$ of $\mathrm{Hg}$ in soil in Chongqing [19]. The Independent-Samples $t$-test showed that soil $\mathrm{Hg}$ concentrations were not statistically different between the two sites $(P>0.05)$.

Mercury concentration in water was $53.70 \pm 6.70 \mathrm{ng} / \mathrm{L}$ $(n=5)$ at $\mathrm{CJ}$ and $29.01 \pm 11.63 \mathrm{ng} / \mathrm{L}(n=5)$ at $\mathrm{CS}$, respectively.
They were not statistically different $(P>0.05)$. Ambient air $\mathrm{Hg}$, measured at the height of $1 \mathrm{~m}$ above soil/water surface, was $0.56-6.89 \mathrm{ng} / \mathrm{m}^{3}$ with an average of $3.07 \mathrm{ng} / \mathrm{m}^{3}(n=781)$ at CJ, and $0.20-6.29 \mathrm{ng} / \mathrm{m}^{3}$ with an average of $2.85 \mathrm{ng} / \mathrm{m}^{3}$ $(n=258)$ at $\mathrm{CS}$.

Mercury exchange fluxes across the air/water surface were -25.08 to $252.38 \mathrm{ng} /\left(\mathrm{m}^{2} \mathrm{~h}\right)$ at $\mathrm{CJ}$, with an average of $20.61 \pm 48.10 \mathrm{ng} /\left(\mathrm{m}^{2} \mathrm{~h}\right)$, and -26.63 to $158.46 \mathrm{ng} /\left(\mathrm{m}^{2} \mathrm{~h}\right)$ at $\mathrm{CS}$, with an average of $4.63 \pm 25.74 \mathrm{ng} /\left(\mathrm{m}^{2} \mathrm{~h}\right.$ ) (Table 1$)$. The larger $\mathrm{Hg}$ exchange fluxes at $\mathrm{CJ}$ might be due to the relatively higher temperature observed at this site (Table 2).

The Hg fluxes were weakly correlated with TGM concentration in air $(r=0.12, P<0.05(n=264)$ at $\mathrm{CS} ; r=0.21, P$ $<0.01(n=395)$ at CJ) (Table 3). However, the annual $\mathrm{Hg}$ emission from paddy field to the air was estimated to be $280.37 \mathrm{~kg} /$ year, accounting for approximately $16 \%$ of total $\mathrm{Hg}$ emissions (about 1.78 t/year estimated by Wang et al. [13]) from natural sources in the studied area. Therefore, paddy fields could be a significant source of atmospheric $\mathrm{Hg}$ in the local region.

\subsection{Effects of environmental factors on $\mathrm{Hg}$ fluxes}

In the studied regions, winter generally starts in early November and last until later March, while summer begins in late May and remain until early September. Spring and autumn are short.

(1) Solar radiation. Higher mercury emission levels were observed when solar radiations were high (Figure 2(a), $\left.R^{2}=0.60, P<0.01\right)$. They had a significant positive correlation $(r=0.73, n=264, P<0.01$ at CS and $r=0.78, n=395$, $P<0.01$ at CJ, respectively; see Table 3 and Figure 3). This was in agreement with previous studies [15,20-23]. The regression analysis showed that mercury emission had a power relation with solar radiation $\left(R^{2}=0.91\right.$ for $\mathrm{CJ}$ and

Table 1 Summary of $\mathrm{Hg}$ exchange fluxes $\left(\mathrm{ng} /\left(\mathrm{m}^{2} \mathrm{~h}\right)\right)$ at two sites, in Beibei, Chongqing, China

\begin{tabular}{|c|c|c|c|c|c|c|c|c|}
\hline & Date & Start-stop & Last (min) & Mean & Max & Min & SD & $n$ \\
\hline \multirow{5}{*}{ Chengjiang } & $2008.04 .15-17$ & $\begin{array}{l}1920-1210 \\
1540-1330\end{array}$ & 2320 & 38.05 & 252.38 & -13.84 & 66.75 & 117 \\
\hline & $2008.05 .12-13$ & $1640-1640$ & 1440 & 8.86 & 78.57 & -16.82 & 21.43 & 71 \\
\hline & $2008.06 .27-28$ & $1525-1145$ & 1220 & 7.36 & 116.13 & -16.96 & 25.18 & 63 \\
\hline & $2008.10 .04-05$ & $1035-1035$ & 1440 & 29.79 & 197.88 & -11.68 & 54.64 & 72 \\
\hline & Date & Start-stop & Last (min) & Mean & $\operatorname{Max}$ & Min & SD & $n$ \\
\hline \multirow{4}{*}{ Caoshang } & 2008.03.18-19 & $\begin{array}{l}1625-0235 \\
0720-1630\end{array}$ & 1160 & 8.21 & 93.70 & -23.89 & 23.97 & 55 \\
\hline & $2008.06 .17-18$ & $1120-1110$ & 1410 & 12.99 & 158.46 & -17.91 & 33.20 & 71 \\
\hline & 2008.07.06-07 & $1025-1025$ & 1440 & 2.38 & 52.23 & -26.63 & 23.38 & 72 \\
\hline & 2008.11 .27 & $1030-1220$ & 110 & 53.06 & 85.95 & 26.49 & 24.45 & 6 \\
\hline
\end{tabular}


Table 2 Summary of environmental parameters of two sampling sites, in Beibei, Chongqing, China

\begin{tabular}{|c|c|c|c|c|c|c|c|}
\hline & Date & Meteorological parameters & Mean & Max & Min & SD & $n$ \\
\hline \multirow{20}{*}{ Chengjiang } & \multirow{4}{*}{$2008.04 .15-17$} & Wind speed $(\mathrm{m} / \mathrm{s})$ & 0.33 & 2.00 & 0.00 & 0.43 & 117 \\
\hline & & Solar radiation(klux) & 16.41 & 95.10 & 0.00 & 27.28 & 117 \\
\hline & & Air temperature $\left({ }^{\circ} \mathrm{C}\right)$ & 21.76 & 40.40 & 13.70 & 6.11 & 117 \\
\hline & & Water temperature $\left({ }^{\circ} \mathrm{C}\right)$ & 20.88 & 29.20 & 16.20 & 3.21 & 117 \\
\hline & \multirow{4}{*}{$2008.05 .12-13$} & Wind speed $(\mathrm{m} / \mathrm{s})$ & 0.26 & 1.20 & 0.00 & 0.32 & 71 \\
\hline & & Solar radiation(klux) & 8.41 & 38.60 & 0.00 & 10.26 & 71 \\
\hline & & Air temperature $\left({ }^{\circ} \mathrm{C}\right)$ & 26.08 & 39.80 & 20.40 & 3.75 & 71 \\
\hline & & Water temperature $\left({ }^{\circ} \mathrm{C}\right)$ & 25.73 & 35.10 & 22.40 & 3.04 & 71 \\
\hline & \multirow{4}{*}{$2008.06 .27-28$} & Wind speed $(\mathrm{m} / \mathrm{s})$ & 0.14 & 1.30 & 0.00 & 0.27 & 63 \\
\hline & & Solar radiation(klux) & 27.74 & 101.83 & 0.00 & 35.82 & 63 \\
\hline & & Air temperature $\left({ }^{\circ} \mathrm{C}\right)$ & 27.39 & 38.80 & 20.10 & 5.32 & 63 \\
\hline & & Water temperature $\left({ }^{\circ} \mathrm{C}\right)$ & 25.33 & 30.00 & 22.30 & 2.34 & 63 \\
\hline & \multirow{4}{*}{$2008.10 .04-05$} & Wind speed $(\mathrm{m} / \mathrm{s})$ & 0.25 & 1.70 & 0.00 & 0.40 & 72 \\
\hline & & Solar radiation(klux) & 20.24 & 96.20 & 0.00 & 29.62 & 72 \\
\hline & & Air temperature $\left({ }^{\circ} \mathrm{C}\right)$ & 24.71 & 31.80 & 19.10 & 3.63 & 72 \\
\hline & & Water temperature $\left({ }^{\circ} \mathrm{C}\right)$ & 24.41 & 32.60 & 20.10 & 4.13 & 72 \\
\hline & \multirow{4}{*}{ 2008.11.09-10 } & Wind speed $(\mathrm{m} / \mathrm{s})$ & 0.37 & 2.10 & 0.00 & 0.57 & 72 \\
\hline & & Solar radiation(klux) & 9.50 & 47.90 & 0.00 & 13.54 & 72 \\
\hline & & Air temperature $\left({ }^{\circ} \mathrm{C}\right)$ & 16.95 & 28.00 & 11.90 & 4.66 & 72 \\
\hline & & Water temperature $\left({ }^{\circ} \mathrm{C}\right)$ & 17.99 & 24.30 & 15.60 & 2.55 & 72 \\
\hline \multirow{21}{*}{ Caoshang } & Date & "Meteorological parameters & Mean & Max & Min & SD & "n \\
\hline & \multirow{4}{*}{ 2008.03.18-19 } & Wind speed $(\mathrm{m} / \mathrm{s})$ & 1.60 & 5.00 & 0.00 & 1.56 & 55 \\
\hline & & Solar radiation(klux) & 19.67 & 73.90 & 0.00 & 21.60 & 55 \\
\hline & & Air temperature $\left({ }^{\circ} \mathrm{C}\right)$ & 16.89 & 23.80 & 9.70 & 4.81 & 55 \\
\hline & & Water temperature $\left({ }^{\circ} \mathrm{C}\right)$ & 17.06 & 21.20 & 13.20 & 2.38 & 55 \\
\hline & \multirow{4}{*}{ 2008.06.17-18 } & Wind speed $(\mathrm{m} / \mathrm{s})$ & 1.15 & 4.50 & 0.00 & 1.13 & 71 \\
\hline & & Solar radiation(klux) & 32.47 & 104.60 & 0.00 & 38.06 & 71 \\
\hline & & Air temperature $\left({ }^{\circ} \mathrm{C}\right)$ & 25.60 & 34.90 & 19.40 & 4.30 & 71 \\
\hline & & Water temperature $\left({ }^{\circ} \mathrm{C}\right)$ & 25.50 & 32.40 & 20.20 & 3.65 & 71 \\
\hline & \multirow{4}{*}{ 2008.07.06-07 } & Wind speed $(\mathrm{m} / \mathrm{s})$ & 0.62 & 3.20 & 0.00 & 0.82 & 72 \\
\hline & & Solar radiation(klux) & 36.86 & 107.70 & 0.00 & 39.68 & 72 \\
\hline & & Air temperature $\left({ }^{\circ} \mathrm{C}\right)$ & 27.85 & 38.00 & 21.10 & 4.65 & 72 \\
\hline & & Water temperature $\left({ }^{\circ} \mathrm{C}\right)$ & 28.01 & 37.50 & 22.20 & 5.27 & 72 \\
\hline & \multirow{4}{*}{$2008.09 .04-05$} & Wind speed(m/s) & 0.39 & 1.80 & 0.00 & 0.53 & 60 \\
\hline & & Solar radiation(klux) & 16.12 & 102.00 & 0.00 & 28.22 & 60 \\
\hline & & Air temperature $\left({ }^{\circ} \mathrm{C}\right)$ & 23.78 & 30.70 & 19.20 & 3.14 & 60 \\
\hline & & Water temperature $\left({ }^{\circ} \mathrm{C}\right)$ & 21.57 & 27.00 & 19.40 & 2.36 & 60 \\
\hline & \multirow{4}{*}{2008.11 .27} & Wind speed $(\mathrm{m} / \mathrm{s})$ & 1.31 & 2.00 & 0.60 & 0.48 & 6 \\
\hline & & Solar radiation(klux) & 68.79 & 83.33 & 55.13 & 14.93 & 6 \\
\hline & & Air temperature $\left({ }^{\circ} \mathrm{C}\right)$ & 18.98 & 20.00 & 17.30 & 1.13 & 6 \\
\hline & & Water temperature $\left({ }^{\circ} \mathrm{C}\right)$ & 13.68 & 14.10 & 12.90 & 0.45 & 6 \\
\hline
\end{tabular}

Table 3 Pearson correlation coefficients between $\mathrm{Hg}$ flux across air/water interface and environmental factors at two sites, in Beibei, Chongqing, China

\begin{tabular}{lrrrr}
\hline Environmental factors & \multicolumn{2}{c}{ CS $(n=264)$} & \multicolumn{1}{c}{ CJ $(n=395)$} \\
\cline { 2 - 5 } & $r$ & $P$ & $r$ & $P$ \\
\hline Air temperature $X 1$ & 0.38 & 0.00 & 0.53 & 0.00 \\
Relative humidity $X 2$ & 0.12 & 0.00 & -0.67 & 0.00 \\
Atmospheric pressure $X 3$ & 0.31 & 0.05 & -0.06 & 0.25 \\
Water temperature $X 4$ & -0.10 & 0.00 & 0.34 & 0.00 \\
Eh $X 5$ & 0.73 & 0.26 & -0.05 & 0.44 \\
Solar radiation $X 6$ & 0.12 & 0.00 & 0.78 & 0.00 \\
Hg concentration in the air $X 7$ & & 0.05 & 0.21 & 0.00 \\
\hline
\end{tabular}



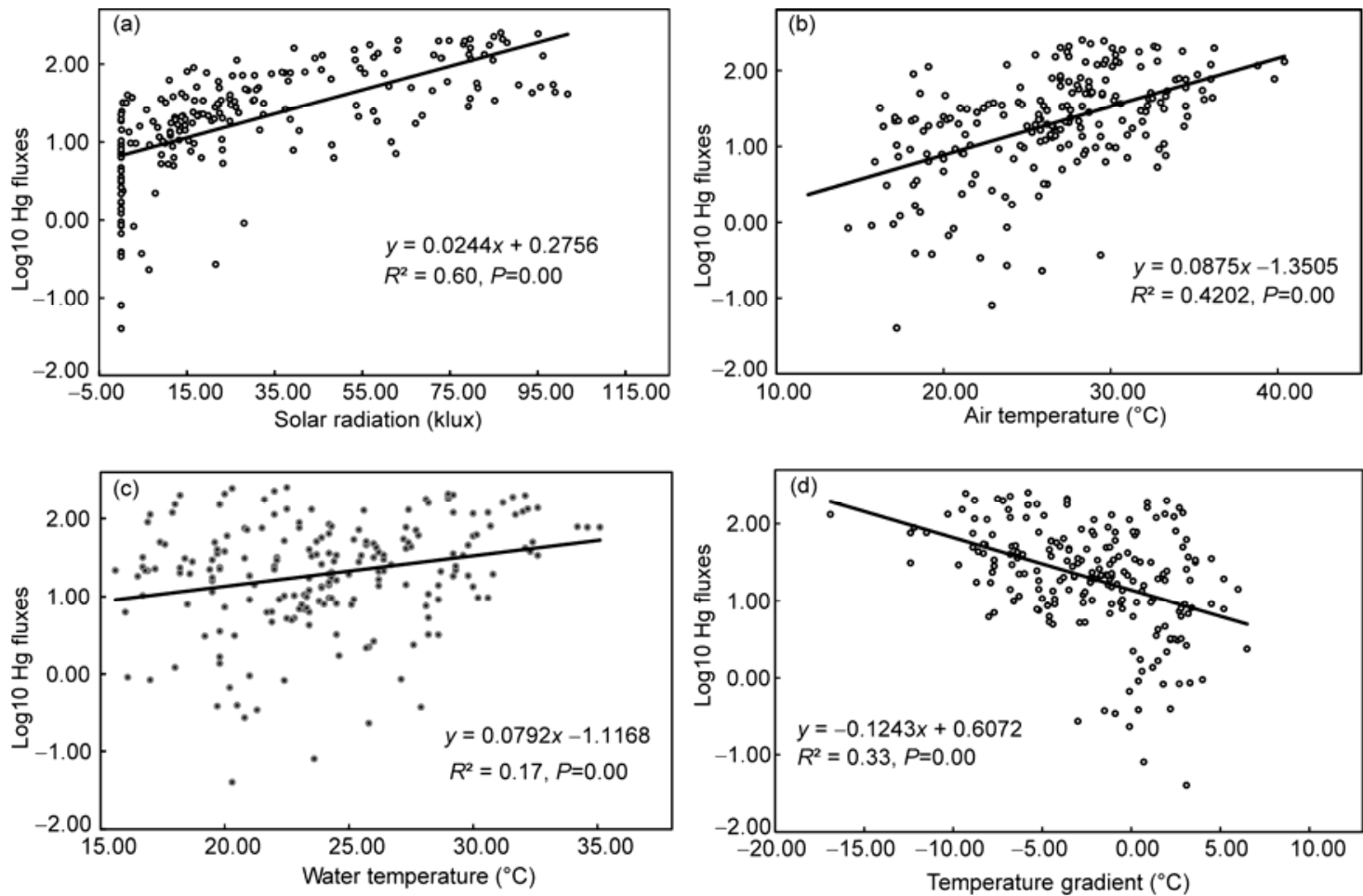

Figure 2 Scatter plots for relations of $\log$ (Hg flux) to environmental parameter. (a) Solar radiation; (b) air temperature; (c) Water temperature; (d) temperature gradient $(\mathrm{Tw}-\mathrm{Ta})$.

$R^{2}=0.86$ for CS) (Figure 4). Previous research demonstrated that photochemical reduction of $\mathrm{Hg}(\mathrm{II})$ and $\mathrm{Hg}(\mathrm{I})$ to $\mathrm{Hg}(0)$ plays an important role in $\mathrm{Hg}$ emission to the atmosphere[21,24]. Amyot et al. [25] found a positive relationship of photoinduced DGM (Dissolved Gas Mercury) production with incident radiations at different times of the year.

Dissolved organic matters (DOM) can act as natural photosensitisers and have an intrinsic capacity to reduce transition metals in natural waters. Due to their ability to absorb light, DOM can enhance photochemical reduction by transferring the absorbed energy to a suitable electron receptor [26]. Thus, solar-mediated reduction and evolution of mercury from natural waters could be enhanced in the presence of DOM [27]. Water in paddy fields should contain DOC because of soil, root exudates and the application of organic manures, possibly accelerating photochemical reduction of $\mathrm{Hg}$ and leading to increased DGM in the surface layer of water in paddy soils.

Solar radiation can enhance mercury emission not only through the reduction of $\mathrm{Hg}^{2+}$ to $\mathrm{Hg}^{0}$, but also through an indirect pathway, increasing water temperature during the conversion of solar energy to thermal energy [18].

(2) Temperature. Greater mercury emissions were also observed when temperatures were higher (Figure 2(b), $R^{2}=0.42, P=0.00$ for air temperature; Figure 2(c), $R^{2}=0.17$, $P<0.01$ for water temperature). Mercury fluxes were significantly positively correlated with air temperature $(r=0.38, n=264, P<0.01$ for CS and $r=0.53, n=395$, $P<0.01$ for $\mathrm{CJ}$, respectively) and water temperature $(r=0.31, n=264, P<0.01$ for CS and $r=0.34, n=395$, $P<0.01$ for CJ, respectively) (Table 3). Regression analysis revealed that mercury emission increased exponentially with water temperature $\left(R^{2}=0.76\right.$ and $R^{2}=0.81$ for CJ and CS, respectively) ( Figure 5), and it followed a power law with air temperature $\left(R^{2}=0.77\right.$ for $\mathrm{CJ}$ and $R^{2}=0.83$ for CS) (Figure 6). An exponential relationship between mercury emission and water temperature was also found on a freshwater surface at Knobesholm, southwestern Sweden $[21,28]$.

Water temperature can affect the saturation potential of dissolved gaseous $\mathrm{Hg}$ in water [29], thus influencing the emission of $\mathrm{Hg}$ in air-water interface. The solubility of $\mathrm{Hg}^{0}$ in water is controlled by water temperature, pressure and water salinity. Under certain pressure and water salinity, $\mathrm{Hg}^{0}$ in water will be supersaturated and release to the air with the temperature increasing.

(3) Other factors. Relative humidity had a negative correlation with mercury fluxes $(r=-0.74, P<0.01$ for CJ and $r=-0.67, P<0.01$ for CS, Table 3). Atmospheric pressure and water Eh did not show significant correlations with mercury fluxes $(P=0.26$ and 0.44 for $E h, P=0.05$ and 0.25 for atmospheric pressure at CJ and CS, respectively, Table 2).

However, relative humidity was found to be significantly negatively correlated with solar radiation $(r=-0.72$, 

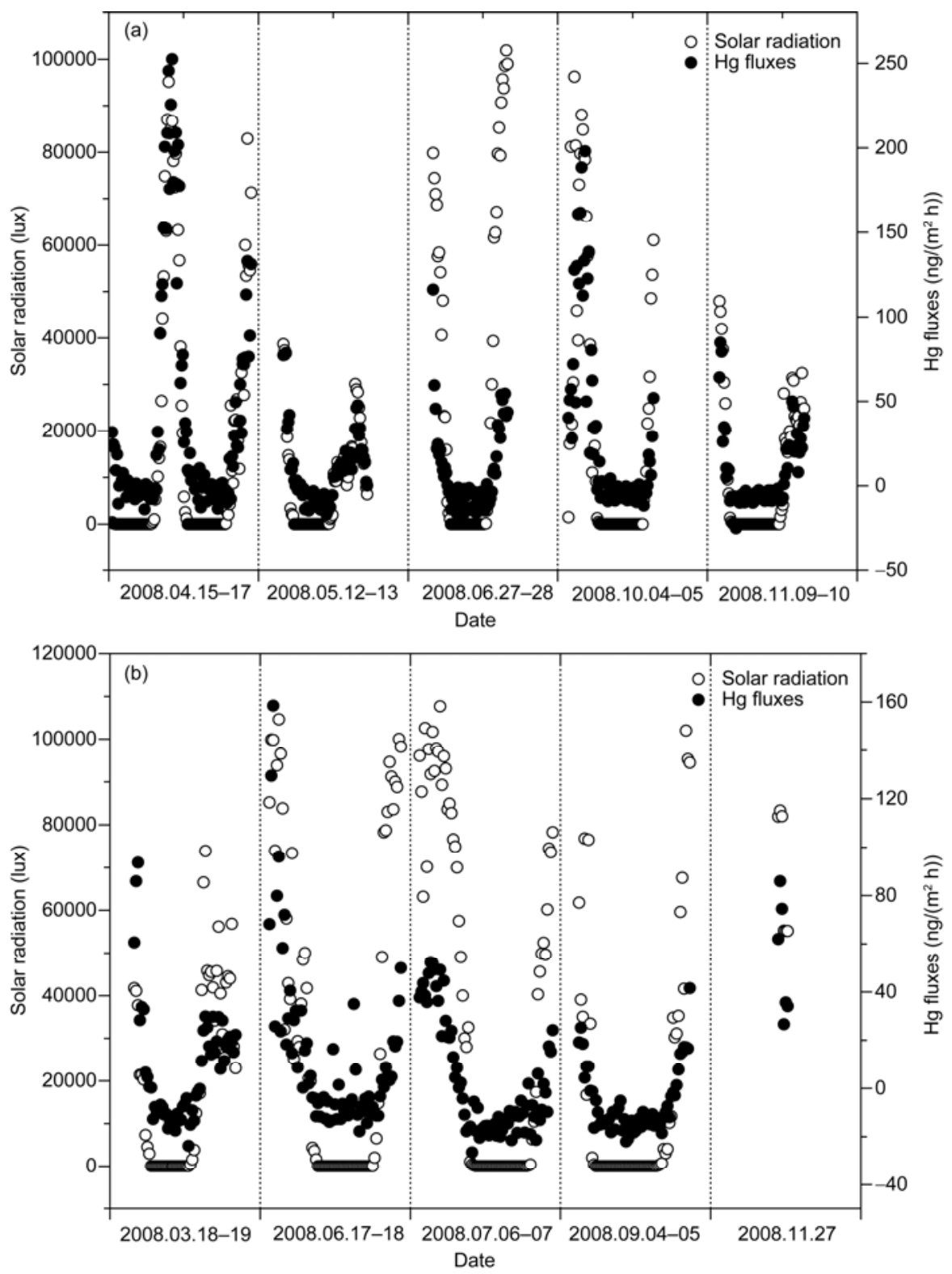

Figure 3 Relationships between mercury fluxes and solar radiation at both sampling sites. (a) CJ, (b) CS.
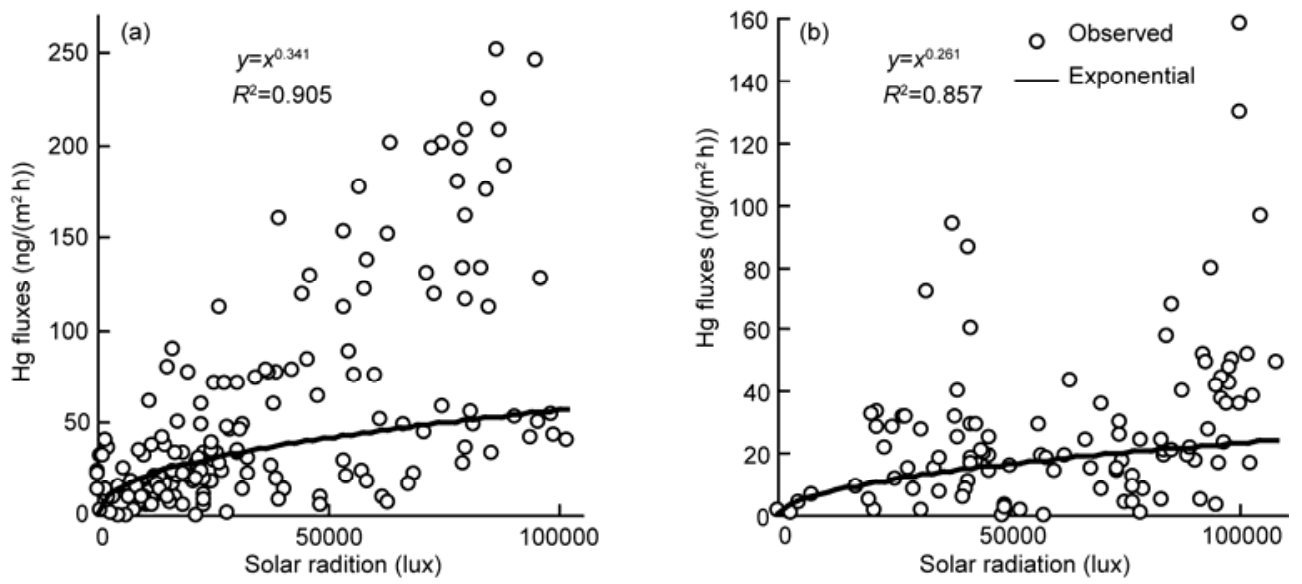

Figure 4 Curvilinear regressions between mercury fluxes and solar radiation. (a) CJ, (b) CS 

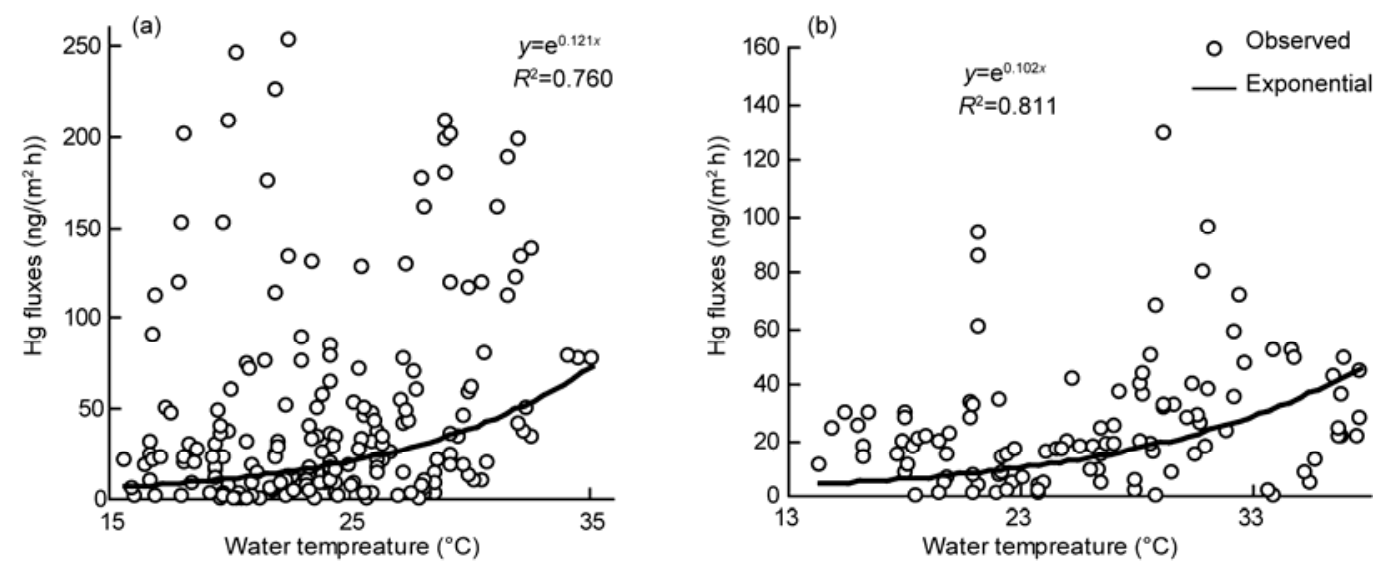

Figure 5 Curvilinear regressions between mercury fluxes and water temperature. (a) CJ, (b) CS.
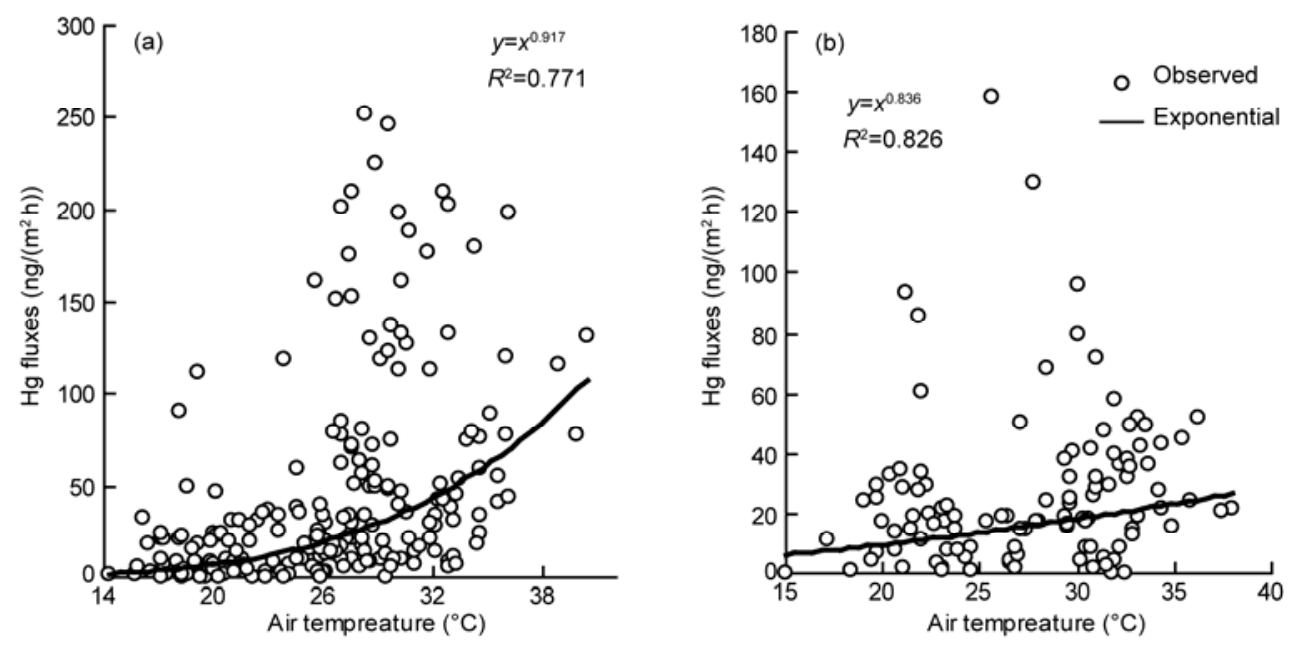

Figure 6 Curvilinear regressions between mercury fluxes and air temperature. (a) CJ, (b) CS.

$P=0.00, n=653)$. Therefore, the negative linear correlation between mercury flux and relative humidity is most likely caused by the collinearity of relative humidity and solar radiation [22,28]. Relative humidity may not be an important factor directly influencing mercury emission [30]. Thus, the effect of relative humidity on $\mathrm{Hg}$ emissions was not considered in our factor analysis.

\subsection{Principal component analysis}

KMO and Bartlett's Test were carried out before performing principal component analysis (PCA). A commonly given rule of thumb on the number of components is that the selected components can explain at least $85 \%$ of the total accumulation of the variation. Based on this rule, the factors could be reduced to four components (see Table 4). Rotated (Varimax rotation) factor loadings and communalities were applied to simplify the explanation for the PCA. At the CJ site, the PCA results showed that 4 principal components explained a total $92.57 \%$ of the observed variation. The first component accounted for $33.62 \%$ of the observed variation.
This component primarily consisted of air temperature, water temperature (positive loading) and atmospheric pressure (negative loading), which were solubility/saturation $\left(\mathrm{Hg}^{0}\right)$ determinants. Component 2 accounted for $22.86 \%$ of the variation, primarily including air temperature, water temperature and solar radiation (positive loading), and was light and heat determinants. Component 3, accounting for $18.46 \%$ of the variation, was Eh determinant. Component 4, $\mathrm{Hg}$ concentration in the air, accounted for $17.63 \%$ of the variation.

Similarly, a total of $94.62 \%$ of the observed variation could be explained by the 4 principal components at the CS site. The "solubility/saturation $\left(\mathrm{Hg}^{0}\right)$ determinant" component accounted for $32.65 \%$ of the observed environmental variation, "light and heat determinant" component for $27.30 \%$, "Eh determinant" component for $17.47 \%$, and "Hg concentration in the air" $17.20 \%$ (Table 4).

\subsection{Path coefficient analysis}

Path coefficient analysis showed that solar radiation, 
Table 4 Rotated (Varimax rotation) factor loadings and communalities for the estimated variables of mercury fluxes at two sites, Beiebi, Chongqing, China (coefficients $> \pm 0.20$ are included)

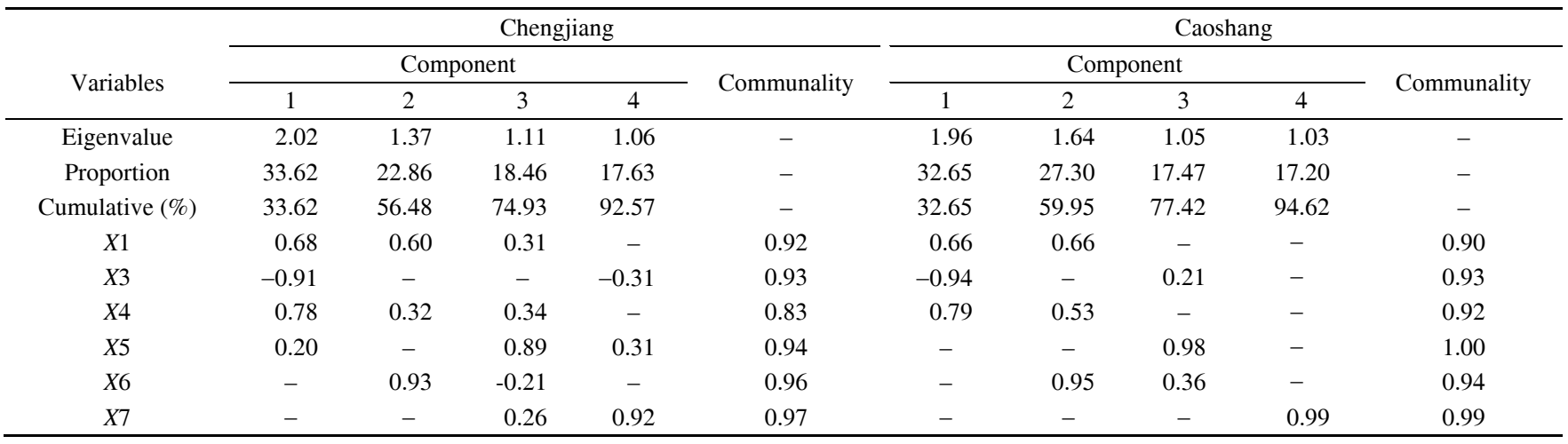

atmospheric pressure, and water temperature had highly positive direct effects $(0.80,0.36$ and 0.25$)$ on mercury emission during the daytime (Table 5). Solar radiation alone made a $83.6 \%$ direct contribution towards mercury emission. Air temperature had the greatest indirect effect on mercury emission (0.51), while air $\mathrm{Hg}$ concentration was the second largest indirect effect $(0.23)$.

Air temperature and water temperature contributed positively towards mercury emission through solar radiation $(0.55,0.21)$ and their indirect effects on mercury emission $(61.65 \%$ and $37.37 \%)$ were higher than their direct effects $(2.24 \%$ and $31.99 \%)$.

At nighttime, water temperature, air $\mathrm{Hg}$ concentration and atmospheric pressure had positive direct effects $(0.93$, 0.16 and 0.06 ) on mercury emission, while air temperature had a negative direct effect $(-0.34)$. However, air temperature had the greatest indirect effect on mercury emission (0.66). The individual direct effect on mercury emission was $71.65 \%, 30.63 \%, 24.79 \%$ and $6.64 \%$ for water temperature, air temperature, air $\mathrm{Hg}$ concentration and atmospheric pressure, respectively.

Water temperature contributed positively towards mercury emission directly $(71.65 \%)$, while air temperature was the largest indirect effect $(64.11 \%)$ (Table 5). Air temperature contributed negatively towards mercury emission by affecting water temperature (20.35), which was smaller than its direct effects $(30.63 \%)$ (Table 5).

In addition, there was a negative linear correlation between $\mathrm{Hg}$ fluxes (positive value) and temperature gradient (Figure 2(d), $R^{2}=0.33, P<0.01$ ). This has been shown in previous studies [31]. At nighttime, the warm air is transported over the relative colder water, and, as a result of that, the water temperature at the surface might increase. Further, with increasing water temperature, the solubility of DGM (dissolved gas mercury) decreases and the water may become supersaturated with respect to DGM. Thus, heat transmission from water to air might facilitate DGM release from water into the air. Therefore, the $\Delta T$ gradient may also be an important factor for mercury emission at nighttime.

\section{Conclusions}

Mercury fluxes at the air/water surface in paddy field were $20.61 \pm 48.10 \mathrm{ng} /\left(\mathrm{m}^{2} \mathrm{~h}\right)$ and $4.63 \pm 25.74 \mathrm{ng} /\left(\mathrm{m}^{2} \mathrm{~h}\right)$ at $\mathrm{CJ}$ and $\mathrm{CS}$, respectively. The paddy field was a significant local atmospheric emission source. Solar radiation and water temperature were the two most important factors affecting $\mathrm{Hg}$ fluxes at air/water surface in paddy field. Mercury emission at the air/water surface in a paddy field increased as a power-law with the increasing solar radiation and air temperature, and exponentially with water temperature.

Table 5 The result of path analysis

\begin{tabular}{|c|c|c|c|c|c|c|c|c|c|c|c|c|c|c|}
\hline & \multirow{2}{*}{ Variables } & \multicolumn{5}{|c|}{ Effect via } & \multicolumn{2}{|c|}{ Path coefficient } & \multirow{2}{*}{$\begin{array}{c}\text { Total } \\
\text { correlation }\end{array}$} & \multicolumn{5}{|c|}{ Effect via (\%) } \\
\hline & & $X 2$ & $X 4$ & $X 5$ & $X 7$ & $X 8$ & Direct effect & Indirect effect & & $X 2$ & $X 4$ & $X 5$ & $X 7$ & $X 8$ \\
\hline \multirow{5}{*}{ Daytime } & $X 2$ & -0.02 & -0.19 & 0.14 & 0.55 & 0.00 & -0.02 & 0.51 & 0.49 & 2.24 & 20.66 & 15.22 & 61.65 & 0.23 \\
\hline & $X 4$ & 0.01 & 0.36 & -0.12 & 0.15 & -0.01 & 0.36 & 0.02 & 0.39 & 1.54 & 55.31 & 18.77 & 22.47 & 1.92 \\
\hline & $X 5$ & -0.01 & -0.18 & 0.25 & 0.21 & 0.01 & 0.25 & 0.03 & 0.28 & 1.66 & 27.32 & 31.99 & 37.37 & 1.67 \\
\hline & $X 7$ & -0.01 & 0.07 & 0.07 & 0.80 & -0.01 & 0.80 & 0.11 & 0.91 & 1.46 & 7.12 & 6.96 & 83.60 & 0.86 \\
\hline & $X 8$ & 0.00 & 0.13 & -0.08 & 0.18 & -0.04 & -0.04 & 0.23 & 0.20 & 0.28 & 30.31 & 18.11 & 42.74 & 8.56 \\
\hline \multirow{3}{*}{ Nighttime } & $X 4$ & 0.16 & 0.06 & -0.56 & - & 0.10 & 0.06 & -0.30 & -0.24 & 18.51 & 6.64 & 63.84 & - & 11.00 \\
\hline & $X 5$ & -0.27 & -0.04 & 0.93 & - & -0.07 & 0.93 & -0.37 & 0.57 & 20.35 & 2.66 & 71.65 & - & 5.35 \\
\hline & $X 8$ & 0.07 & 0.03 & -0.40 & - & 0.16 & 0.16 & -0.30 & -0.13 & 10.09 & 5.14 & 59.99 & - & 24.79 \\
\hline
\end{tabular}


Temperature gradient might be an important factor that facilitated the transfer of volatile mercury from water to the air at nighttime.

The authors are very much grateful to Dr. Cong Tu at the Department of Plant Pathology, North Carolina State University, for his valuable suggestions and assistance to the revised manuscript. This work was supported by the National Natural Science Foundation of China (40673063 and 40973079), the "211" Ecology National Key Discipline of Southwest University, and Postgraduates' Science \& Technological Innovation Fund of Southwest University (kb2010019).

1 Khush G S. Origin, dispersal, cultivation and variation of rice. Plant Mol Biol, 1997, 35: 25-34

2 Yoon C G. Wise use of paddy rice fields to partially compensate for the loss of natural wetlands. Paddy Water Environ, 2009, 7: 357-366

3 Nakagawa R, Yumita Y. Change and behavior of residual mercury in paddy soils and rice of Japan. Chemosphere, 1998, 37: 1483-1487

4 Grigal D F. Inputs and outputs of mercury from terrestrial watersheds: A review. Environ Rev, 2002, 10: 1-39

5 Kuiken T, Gustin M S, Zhang H, et al. Mercury emission from terrestrial background surfaces in the eastern USA. II: Air/surface exchange of mercury within forests from South Carolina to New England. Appl Geochem, 2008, 23: 356-368

6 Kuiken T, Zhang H, Gustin M S, et al. Mercury emission from terrestrial background surfaces in the eastern USA. Part I: Air/surface exchange of mercury within a southeastern deciduous forest (Tennessee) over one year. Appl Geochem, 2008, 23: 345-355

7 During A, Rinklebe J, Bohme F, et al. Mercury volatilization from three floodplain soils at the Central Elbe River, Germany. Soil Sediment Contam, 2009, 18: 429-444

8 Poissant L, Pilote M, Constant P, et al. Mercury gas exchanges over selected bare soil and flooded sites in the bay St. Francois wetlands (Quebec, Canada). Atmos Environ, 2004, 38: 4205-4214

9 Obrist D, Gustin M S, Arnone J A, et al. Measurements of gaseous elemental mercury fluxes over intact tallgrass prairie monoliths during one full year. Atmos Environ, 2005, 39: 957-965

10 Engle M A, Gustin M S, Johnson D W, et al. Mercury distribution in two Sierra forest and one desert sagebrush steppe ecosystems and the effects of fire. Sci Total Environ, 2006, 367: 222-233

11 Kim K H, Kim M Y, Kim J, et al. Effects of changes in environmental conditions on atmospheric mercury exchange: Comparative analysis from a rice paddy field during the two spring periods of 2001 and 2002. J Geophys Res, 2003, 108: 4607

12 Gustin M S, Lindberg S E, Weisberg P J. An update on the natural sources and sinks of atmospheric mercury. Appl Geochem, 2008, 23: 482-493

13 Wang D Y, He L, Shi X J, et al. Release flux of mercury from different environmental surfaces in Chongqing, China. Chemosphere, 2006, 64: 1845-1854

14 Xiao Z F, Munthe J, Schroeder W H, et al. Vertical fluxes of volatile mercury over forest soil and lake surfaces in Sweden. Tellus, 1991, 43B: $267-279$

15 Ferrara R, Mazzolai B. A dynamic flux chamber to measure mercury emission from aquatic systems. Sci Total Environ, 1998, 215: 51-57

16 Sun X, He J, Tan H. Volatile flux of mercury measurement over Hongfeng lake in Guizhou province, China (in Chinese). Lacustrine Sci, 2001, 13, 89-92

17 Lindberg S E, Price J L. Airborne emissions of mercury from municipal landfill Operations: A short-term measurement study in Florida. J Air Waste Manage, 1999, 49: 520-532

18 Zhang H, Lindberg S E, Marsik F J. Mercury air/surface exchange kinetics of background soils of the Tahquamenon river in the Michigan upper peninsula. Water Air Soil Pollution, 2001, 126: 151-169

19 Mou S S, Qing C L. Environmental Soil Science (in Chinese). Beijing: Agricultural Press of China, 1993. 80

20 Costa M, Liss P. Photoreduction and evolution of mercury from seawater. Sci Total Environ, 2000, 261: 125-135

21 Feng X B. The total mercury exchange fluxes over air/natural water surface in summer. Sci China Ser D-Earth Sci, 2002, 32: 609-616

22 Feng X B, Yan H Y, Wang S F, et al. Seasonal variation of gaseous mercury exchange rate between air and water surface over Baihua reservoir, Guizhou, China. Atmos Environ, 2004, 38: 4721-4732

23 Zhu J S, Wang D Y, Liu X, et al. Mercury fluxes from air/surface interfaces in paddy field and dry land. Appl Geochem, 2011, 26: 249-255

24 Amyot M, Lean D, Mierle G. Photochemical formation of volatile mercury in high arctic lakes. Environ Toxicol Chem, 1997, 16: 2054-2063

25 Amyot M, Mierle G, Lean D, et al. Sunlight-induced Formation of Dissolved Gaseous Mercury in Lake Waters. Environ Sci Technol, 1994, 28: 2366-2371

26 Nriagu J O. Mechanistic steps in the photoreduction of mercury in natural waters. Sci Total Environ, 1994, 149: 167-181

27 Costa M, Liss P. Photoreduction of mercury in seawater and its possible implications for $\mathrm{Hg}^{0}$ air-sea fluxes. Mar Chem, 1999, 68: 87-95

28 Gårdfeldt K, Feng X, Sommar J, et al. Total gaseous mercury exchange between air and water at river and sea surfaces in Swedish coastal regions. Atmos Environ, 2001, 35: 3027-3038

29 Andersson M E, Gårdfeldt K, Wängberg I, et al. Seasonal and daily variation of mercury evasion at coastal and off shore sites from the Mediterranean Sea. Mar Chem, 2007, 104: 214-226

30 Gillis A, Miller D R. Some potential errors in the measurement of mercury gas exchange at the soil surface using a dynamic flux chamber. Sci Total Environ, 2000, 260: 181-189

31 Marks R, Beldowska M. Air-sea exchange of mercury vapour over the Gulf of Gdansk and southern Baltic Sea. J Mar Syst, 2001, 27: $315-324$

Open Access This article is distributed under the terms of the Creative Commons Attribution License which permits any use, distribution, and reproduction in any medium, provided the original author(s) and source are credited. 